\title{
Purification and properties of an ethylene-forming enzyme from Pseudomonas syringae pv. phaseolicola PK2
}

\author{
Kazuhiro Nagahama, ${ }^{1}$ Takahira Ogawa, ${ }^{1}$ Takao FujiI, ${ }^{1}$ Masato Tazaki, ${ }^{2}$ Sumio Tanase, ${ }^{3}$ \\ YOSHIMASA MORINO ${ }^{3}$ and Hideo FUKUdA ${ }^{1 *}$
}

Departments of ${ }^{1}$ Applied Microbial Technology and ${ }^{2}$ Industrial Chemistry, The Kumamoto Institute of Technology, Ikeda 4-22-1, Kumamoto 860, Japan

${ }^{3}$ Kumamoto University Medical School, Honjo 2-2-1, Kumamoto 860, Japan

(Received 2 May 1991; revised 26 June 1991; accepted 8 July 1991)

\begin{abstract}
A novel ethylene-forming enzyme that catalyses the formation of ethylene from 2-oxoglutarate was purified from a cell-free extract of Pseudomonas syringae pv. phaseolicola PK2. It was purified about 2800 -fold with an overall yield of $53 \%$ to a single band of protein after SDS-PAGE. The purified enzyme had a specific activity of $660 \mathrm{nmol}$ ethylene min $^{-1}$ (mg protein) ${ }^{-1}$. The molecular mass of the enzyme was approximately $36 \mathrm{kDa}$ by gel filtration and $42 \mathrm{kDa}$ by SDS-PAGE. The isoelectric point and optimum pH were 5.9 and ca. 7.0-7.5, respectively. There was no homology between the $\mathbf{N}$-terminal amino acid sequence of the ethylene-forming enzyme of Ps. syringae pv. phaseolicola PK2 and the sequence of the ethylene-forming enzyme of the fungus Penicillium digitatum IFO 9372. However, the two enzymes have the following properties in common. The presence of 2-oxoglutarate, $L$-arginine, $\mathrm{Fe}^{2+}$ and oxygen is essential for the enzymic reaction. The enzymes are highly specific for 2-oxoglutarate as substrate and L-arginine as cofactor. EDTA, Tiron, DTNB [5,5'-dithio-bis(2-nitrobenzoate)] and hydrogen peroxide are all effective inhibitors.
\end{abstract}

\section{Introduction}

It is well known that ethylene is produced by various plants and can act as a plant hormone. There have also been many reports of ethylene production by aerobic heterotrophic micro-organisms. The ethylene-forming enzyme in plants, which converts 1-aminocyclopropane1-carboxylic acid (ACC) to ethylene, has not yet been isolated (Kende, 1989), but the characteristics of microbial ethylene-forming enzymes have gradually become clearer during the past decade. Two precursors of microbial ethylene production have been identified, namely 2-oxo-4-methylthiobutyric acid (KMBA), a deaminated derivative of $\mathrm{L}$-methionine, and 2-oxoglutarate. The former precursor is used in so-called L-methionine-dependent ethylene-forming microbes and the latter in so-called 2-oxoglutarate-dependent ethyleneforming microbes.

Ince \& Knowles (1986) reported the formation of

Abbreviations: ACC, 1-aminocyclopropane-1-carboxylic acid; KMBA, 2-oxo-4-methylthiobutyric acid; DTNB, 5,5'-dithiobis(2-nitrobenzoate). ethylene from KMBA by cell-free extracts of Escherichia coli. KMBA was converted to ethylene, methanethiol and probably carbon dioxide by a soluble enzyme system that required the presence of oxygen. Subsequently, Fukuda et al. $(1989 b)$ reported the purification of an ethylene-forming enzyme from the yeast Cryptococcus albidus that was active using the same in vitro system, and Ogawa et al. (1990) reported the mechanism of ethylene formation by this enzyme system. The physiology and biochemistry of ethylene production by $E$. coli SPAO were studied by Shipston \& Bunch (1989), and Mansouri $\&$ Bunch (1989) examined the ethylenogenic capabilities of other bacteria grown in media supplemented with L-methionine and KMBA.

Fukuda et al. (1986) reported the partial purification of an ethylene-forming enzyme from the fungus Penicillium digitatum IFO 9372, which produces ethylene from 2-oxoglutarate. The enzyme system in vitro required $\mathrm{L}$-arginine and $\mathrm{Fe}^{2+}$ in the presence of reducing agents such as DTT and oxygen as essential factors. This ethylene-forming enzyme has been purified to an electrophoretically homogeneous state (Fukuda et al., 1989a). Pseudomonas syringae pv. phaseolicola PK2 
(Kudzu strain) is a 2-oxoglutarate-dependent ethyleneproducing bacterium (Goto et al., 1985; Goto \& Hyodo, 1987). Recently, we constructed an ethylene-forming system using an extract of this bacterium (Nagahama et al., 1991). This system was very similar to that prepared from $P$. digitatum, except for the presence of $\mathrm{L}$-histidine. Therefore, it seems to be of interest to compare the properties of the ethylene-forming enzymes from $P$. digitatum and Ps. syringae.

In the present paper, we describe a method for the purification of the ethylene-forming enzyme from Ps. syringae pv. phaseolicola $\mathrm{PK} 2$ and show that the purified ethylene-forming enzyme has remarkably similar properties to those of the enzyme from $P$. digitatum.

\section{Methods}

Micro-organism and culture conditions. All experiments were done with Pseudomonas syringae pv. phaseolicola strain PK2, obtained from Professor M. Goto (Shizuoka University, Shizuoka, Japan). Methods for cultivation were those described previously (Nagahama et al., 1991).

Purification of the ethylene-forming enzyme of Ps. syringae.

All steps of the purification were done at $4{ }^{\circ} \mathrm{C}$ unless otherwise indicated.

(l) Preparation of a cell-free extract. Cells were harvested from 9 litres of culture broth by centrifugation at $14000 \mathrm{~g}$ for $10 \mathrm{~min}$. They were washed twice with deionized water and suspended in $250 \mathrm{ml}$ potassium phosphate buffer ( $\mathrm{pH} 7 \cdot 0$ ). The cells were disrupted by sonication (Branson Sonifier, model 350) for $5 \mathrm{~min}$ with $30 \mathrm{~s}$ intervals for cooling between each $30 \mathrm{~s}$ period of sonication. The intact cells and cell debris were removed by centrifugation $(24000 \mathrm{~g}, 30 \mathrm{~min})$ and the supernatant obtained was used as the cell-free extract.

(2) Treatment with streptomycin sulphate. To precipitate nucleic acids, streptomycin sulphate (at a final concentration of $1 \%$ w/v) was added to the cell-free extract. After stirring the mixtures for $60 \mathrm{~min}$, the sediment was removed by centrifugation at $24000 \mathrm{~g}$ for $20 \mathrm{~min}$. The supernatant obtained was used as the crude enzyme.

(3) Chromatography on Butyl-Toyopearl HW 650M. Ammonium sulphate was added to the solution of crude enzyme to $30 \%$ saturation. The precipitate was removed by centrifugation at $24000 \mathrm{~g}$ for $20 \mathrm{~min}$, and the supernatant was applied to a column $(4 \times 8 \mathrm{~cm})$ of ButylToyopearl HW 650M (Tosoh), which had been equilibrated with buffer A (10 mM-potassium phosphate buffer, $\mathrm{pH} 7 \cdot 0$, containing $1 \mathrm{mM}$-DTT) supplemented with ammonium sulphate to $30 \%$ saturation. The column was washed with the following buffers in turn: $100 \mathrm{ml}$ of buffer A supplemented with ammonium sulphate to $30 \%$ saturation and $300 \mathrm{ml}$ of buffer A supplemented with ammonium sulphate to $15 \%$ saturation. The flow rate was $2.05 \mathrm{ml} \mathrm{cm}^{-2} \mathrm{~h}^{-1}$ and the ethyleneforming enzyme was eluted from the column with $250 \mathrm{ml}$ of buffer $A$. Active fractions were pooled and concentrated by ultrafiltration on a Diaflo YM10 membrane (Amicon). The concentrated solution of enzyme was dialysed in buffer B (10 mM-potassium phosphate buffer, pH 7.5, containing $1 \mathrm{~mm}$-DTT).
(4) Chromatography on DEAE-Sepharose CL-6B. The dialysed solution of enzyme was applied to a column $(4 \times 7 \mathrm{~cm})$ of DEAESepharose CL-6B (Pharmacia) which had been equilibrated with buffer $B$. The column was washed with about 1 vol. $(80 \mathrm{ml})$ of buffer $B$ and eluted with a linear gradient $(800 \mathrm{ml})$ from 0 to $0.25 \mathrm{M}-\mathrm{KCl}$ in buffer $B$ at a flow rate of $6 \mathrm{ml} \mathrm{cm}^{-2} \mathrm{~h}^{-1}$. Fractions containing ethyleneforming activity were pooled and concentrated by ultrafiltration on a Diaflo YM10 membrane.

(5) Chromatography on Bio-Gel HT. The concentrated solution of enzyme was dialysed against buffer $\mathrm{C}(20 \mathrm{mM}-\mathrm{HEPES} / \mathrm{NaOH}$ buffer, pH 7.5, containing $1 \mathrm{~mm}$-DTT) containing $1 \mathrm{~mm}-$ EDTA for $12 \mathrm{~h}$ and applied to a column $(2.8 \times 5 \mathrm{~cm})$ of Bio-Gel HT (Bio-Rad), which had been pre-equilibrated with buffer $\mathrm{C}$. For elution a linear gradient $(300 \mathrm{ml})$ from buffer $C$ to buffer $B$ at a flow rate of $4.3 \mathrm{ml} \mathrm{cm}^{-2} \mathrm{~h}^{-1}$ was used. Active fractions were pooled and concentrated by ultrafiltration on a Diaflo YM10 membrane.

(6) Gel filtration. The concentrated solution of enzyme $(2 \mathrm{ml})$ was applied to a column $(2 \times 88 \mathrm{~cm})$ of Sephadex G-100 (Pharmacia) which had been pre-equilibrated with $10 \mathrm{~mm}$-potassium phosphate buffer, pH 7.0 and eluted at a rate of $2.3 \mathrm{ml} \mathrm{cm}^{-2} \mathrm{~h}^{-1}$.

Purified ethylene-forming enzyme of $P$. digitatum IFO 9372. This was obtained from the cell-free extract as reported previously (Fukuda $e t$ al., 1989a).

Amino-terminal sequence of the purified ethylene-forming enzymes of Ps. syringae and $P$. digitatum. The $\mathrm{N}$-terminal amino acid residues of the purified enzymes of $P$ s. syringae and $P$. digitatum $(20 \mu \mathrm{g}$, equivalent to approx. $480 \mathrm{pmol}$ each) were determined by automated Edman sequencing with a 477A amino acid sequencer (Applied Biosystems).

Electrophoresis. SDS-PAGE was used to check the purity of the protein and to determine the molecular mass of the purified enzyme of Ps. syringae under denaturing conditions. SDS-PAGE was done in $12.5 \%(\mathrm{w} / \mathrm{v})$ polyacrylamide slab gels by the method of Laemmli (1970). Isoelectric points (pIs) of the ethylene-forming enzymes of Ps. syringae and $P$. digitatum were determined with a PhastSystem and Pharmalyte 3-10 (Pharmacia).

Protein determinations. The concentration of protein was measured as the absorbance at $280 \mathrm{~nm}$ or by the Lowry method with bovine serum albumin as standard.

Ethylene formation. The assay for the formation of ethylene by Ps. syringae enzyme was done using a standard reaction mixture $(1 \mathrm{ml})$ which contained $0.2 \mathrm{ml} 200 \mathrm{mM}$-HEPES/NaOH buffer ( $\mathrm{pH} 7.5), 0.1 \mathrm{ml}$ $2.5 \mathrm{~mm}$-2-oxoglutarate, $0.1 \mathrm{ml} 2 \mathrm{mM}-\mathrm{FeSO}_{4}, 0.1 \mathrm{ml} 20 \mathrm{mM}$-DTT, $0.1 \mathrm{ml}$ $100 \mathrm{mM}$-L-histidine, $0.1 \mathrm{ml} 2 \mathrm{mM}$-L-arginine, $0.2 \mathrm{ml}$ of deionized water and $0.1 \mathrm{ml}$ of a solution of enzyme. In the case of $P$. digitatum, the reaction mixture $(1 \mathrm{ml})$ comprised $0.1 \mathrm{ml} 200 \mathrm{mM}-\mathrm{HEPES} / \mathrm{NaOH}$

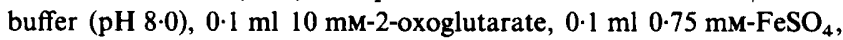
$0.1 \mathrm{ml} 20 \mathrm{mM}$-DTT, $0.1 \mathrm{ml} 10 \mathrm{mM}$-L-arginine, $0.4 \mathrm{ml}$ of deionized water and $0.1 \mathrm{ml}$ of a solution of enzyme. A test-tube $(15 \mathrm{~mm}$ diam., $13 \mathrm{ml}$ capacity) containing each reaction mixture was sealed with a rubber stopper and then incubated on a reciprocal shaker (120 r.p.m.) at $25^{\circ} \mathrm{C}$ for $10 \mathrm{~min}$. After incubation, a sample of gas $(1 \mathrm{ml})$ was withdrawn through the stopper with a gas syringe and the amount of ethylene in the sample was determined with a gas chromatograph (G3800; Yanako) under the following conditions: column size, $3 \mathrm{~mm} \times 2 \mathrm{~m}$; solid phase, active alumina; temperature, $100^{\circ} \mathrm{C}$; carrier gas, nitrogen at a flow rate of $40 \mathrm{ml} \mathrm{min}^{-1}$; and detector, flame ionization. The rate of ethylene production was calculated as previously described (Fukuda et al., 1984). One unit of enzyme activity was defined as the amount of enzyme that catalyses the formation of $1 \mathrm{nmol}$ ethylene min $^{-1}$ under the specified reaction conditions. The specific activity is expressed as units (mg protein) ${ }^{-1}$. 
Table 1. Purification of the ethylene-forming enzyme

The volume of culture broth used was 9 litres.

\begin{tabular}{lcccrr}
\hline \hline \multicolumn{1}{c}{ Purification step } & $\begin{array}{c}\text { Total } \\
\text { protein } \\
\text { (mg) }\end{array}$ & $\begin{array}{c}\text { Total activity } \\
\text { (units) }\end{array}$ & $\begin{array}{c}\text { Specific activity } \\
\text { [units (mg protein) }\end{array}$ & $\begin{array}{c}\text { Yield } \\
\text { (\%) }\end{array}$ & $\begin{array}{c}\text { Purification } \\
\text { (-fold) }\end{array}$ \\
\hline Cell-free extract & 20000 & 4700 & $0 \cdot 24$ & 100 & 1 \\
Streptomycin-treated fraction & 7200 & 4800 & 0.67 & 102 & 3 \\
Butyl-Toyopearl fraction & 290 & 3500 & 12 & 74 & 50 \\
DEAE-Sepharose fraction & 18 & 2600 & 140 & 55 & 580 \\
Bio-Gel fraction & $9 \cdot 4$ & 4300 & 460 & 91 & 1900 \\
Sephadex fraction & $3 \cdot 8$ & 2500 & 660 & 53 & 2800 \\
\hline \hline
\end{tabular}

Table 2. Comparison of some properties of the ethyleneforming enzymes from Ps. syringae and P. digitatum

\begin{tabular}{|c|c|c|c|}
\hline & & Ps. syringae & P. digitatum \\
\hline \multirow{5}{*}{$\begin{array}{l}\text { Molecular } \\
\text { mass } \\
\text { pI } \\
\text { pH }\end{array}$} & Sephadex G-100 & ca. $36 \mathrm{kDa}$ & ca. $42 \mathrm{kDa}$ \\
\hline & SDS-PAGE & ca. $42 \mathrm{kDa}$ & ca. $42 \mathrm{kDa}$ \\
\hline & & 5.9 & 5.9 \\
\hline & Optimum & ca. $7 \cdot 0-7 \cdot 5$ & ca. $7 \cdot 0-7 \cdot 5$ \\
\hline & $\begin{array}{l}\text { Stability } \\
\left(14 \mathrm{~h} \text { at } 5^{\circ} \mathrm{C}\right)\end{array}$ & ca. $6 \cdot 0-8 \cdot 0$ & ca. $6 \cdot 0-8 \cdot 0$ \\
\hline \multirow[t]{3}{*}{ Temperature } & Optimum & & \\
\hline & (for $10 \mathrm{~min}$ ) & ca. $20-25^{\circ} \mathrm{C}$ & $25^{\circ} \mathrm{C}$ \\
\hline & $\begin{array}{l}\text { Stability } \\
\text { (for } 10 \mathrm{~min} \text { ) }\end{array}$ & $\begin{array}{l}\text { Stable below } \\
30^{\circ} \mathrm{C}\end{array}$ & $\begin{array}{l}\text { Stable below } \\
30^{\circ} \mathrm{C}\end{array}$ \\
\hline \multirow[t]{3}{*}{$K_{\mathrm{m}}$ value } & $\mathrm{Fe}^{2+}$ & $5.9 \times 10^{-5} \mathrm{M}$ & $4.0 \times 10^{-5} \mathrm{M}$ \\
\hline & L-Arginin & $1.8 \times 10^{-5} \mathrm{M}$ & $6.0 \times 10^{-5} \mathrm{M}$ \\
\hline & 2-Oxoglutarate & $1.9 \times 10^{-5} \mathrm{M}$ & $3.8 \times 10^{-5} \mathrm{M}$ \\
\hline
\end{tabular}

\section{Results and Discussion}

\section{Purification of the ethylene-forming enzyme from} $P s$. syringae pv. phaseolicola PK2

The ethylene-forming enzyme from Ps. syringae pv. phaseolicola PK2 was purified from 9 litres of culture broth by column chromatography on Butyl-Toyopearl HW 650M, DEAE-Sepharose CL-6B, Bio-Gel HT and Sephadex G-100 as described in Methods (see Table 1). The enzyme was purified about 2800 -fold from the cellfree extract to a specific activity of 660 units $(\mathrm{mg}$ protein $)^{-1}$ with a recovery of $53 \%$. Only one band was observed when the final preparation of enzyme was subjected to SDS-PAGE and the gel was stained with Coomassie blue (data not shown). It should be noted that the yield from the DEAE-Sepharose column to the BioGel column rose to $165 \%$. This result was dependent on the conditions of dialysis because the activity could be approximately doubled or halved during the dialysis. When we did not include $1 \mathrm{~mm}$-EDTA in buffer C during the dialysis, the activity of the fraction from the Bio-Gel column decreased to about $50 \%$ of that of the fraction from the DEAE-Sepharose column (data not shown). Though these phenomena were reproducible, no explanation for them is available as yet.

\section{Some properties of the purified ethylene-forming enzyme}

Table 2 shows a comparison of some properties of the purified ethylene-forming enzyme of Ps. syringae with those of the purified ethylene-forming enzyme of $P$. digitatum. The molecular mass of the enzyme of Ps. syringae, calculated from gel-filtration on a column of Sephadex G-100, was $36 \mathrm{kDa}$; a value of $42 \mathrm{kDa}$ was obtained by SDS-PAGE (data not shown). These results indicate that the enzyme of Ps. syringae is a monomeric protein. The isoelectric point was 5.9 on the PhastSystem (Pharmacia). The optimum $\mathrm{pH}$ and temperature were ca. $7 \cdot 0-7 \cdot 5$ and ca. $20-25^{\circ} \mathrm{C}$, respectively. The $K_{\mathrm{m}}$ values for $\mathrm{Fe}^{2+}$, L-arginine and 2-oxoglutarate were $5.9 \times 10^{-5}$, $1.8 \times 10^{-5}$ and $1.9 \times 10^{-5} \mathrm{M}$, respectively. The properties of the ethylene-forming enzyme of $P$. digitatum are almost the same as that of Ps. syringae (see Table 2).

\section{$N$-Terminal amino acid sequence of the ethylene-forming enzymes of Ps. syringae and P. digitatum}

The N-terminal amino acid sequence of the ethyleneforming enzyme of Ps. syringae was determined and compared with that of $P$. digitatum (see Fig. 1). There was no homology between the $\mathrm{N}$-terminal amino acid sequences of the two enzymes, although they have similar properties (Table 2; see also Tables 3 and 4). It should be noted that about $25 \%$ of the entire preparation of purified enzyme from Ps. syringae lacked an $\mathrm{N}$ terminal methionine residue. Waller (1963) reported that only $40 \%$ of the polypeptide chains retain an $\mathrm{N}$-terminal methionine residue; instead, about $50 \%$ of chains have alanine, serine or threonine at their amino termini. According to Hirel et al. (1989), the excision of the Nterminal methionine is catalysed by a methionyl-amino 
Ps. syringae pv. phaseolicola PK2

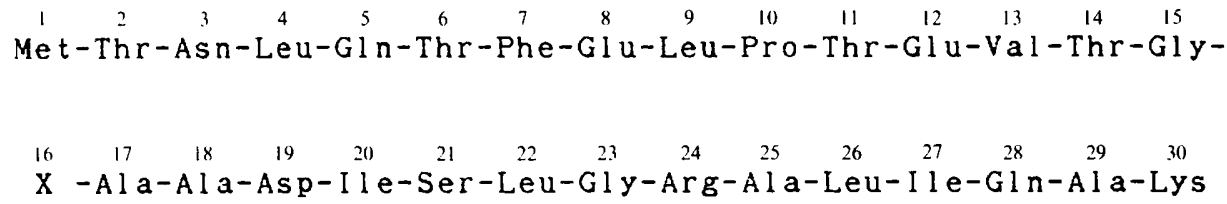

$P$. digitatum

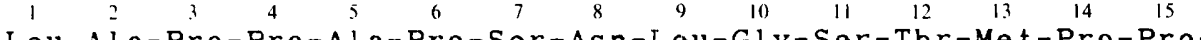

Leu-Ala-Pro-Pro-Ala-Pro-Ser-Asn-Leu-Gly-Ser-Thr-Met-Pro-Pro-

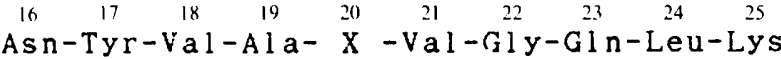

Fig. 1. Comparison of the N-terminal amino acid sequences of the ethylene-forming enzymes from Ps. syringae and $P$. digitatum.

peptidase. The ethylene-forming enzyme of Ps. syringae may therefore be susceptible to such a peptidase.

\section{Substrate and cofactor specificity}

The optimal concentrations of the compounds essential for the formation of ethylene by the purified ethyleneforming enzyme of Ps. syringae were determined. The optimal concentrations of 2-oxoglutarate, $\mathrm{Fe}^{2+}$, L-histidine and L-arginine were ca. $0.2-0.4 \mathrm{~mm}, 0 \cdot 2-0.4 \mathrm{~mm}, 2$ $10 \mathrm{~mm}$ and $0 \cdot 1-0 \cdot 2 \mathrm{mM}$, respectively (data not shown). It should be noted that (1) 2-oxoglutarate, $\mathrm{Fe}^{2+}$ and $\mathrm{L}$ arginine were absolutely essential for the formation of ethylene, there being no activity when any of these compounds was omitted from the reaction mixture; (2) the optimal concentrations of these three compounds were almost the same (ca. $0.2 \mathrm{mM}$ ); (3) L-histidine was not essential for the formation of ethylene; and (4) DTT was not needed at all. It is noteworthy that the enzyme system required oxygen as an essential factor (data not shown). The substrate specificity and cofactor specificity of the ethylene-forming enzyme of Ps. syringae were examined by replacing 2-oxoglutarate, $\mathrm{L}$-arginine and Lhistidine, respectively, with various alternative compounds. The ethylene-forming enzyme was highly specific for 2-oxoglutarate (data not shown) and Larginine (see Table $3 a$ ) and L-histidine (see Table $3 b$ ). The respective ethylene-forming activities in the pres-

Table 3. Cofactor specificity of the ethylene-forming enzyme from Ps. syringae

The specific activity of the ethylene-forming enzyme used was 660 units (mg protein) ${ }^{-1}$.

\begin{tabular}{|c|c|c|c|}
\hline \multicolumn{2}{|l|}{ (a) } & \multicolumn{2}{|c|}{ (b) } \\
\hline Cofactor $(0.2 \mathrm{mM})$ & $\begin{array}{c}\text { Relative } \\
\text { ethylene-forming }\end{array}$ & Cofactor $(10 \mathrm{mM})$ & $\begin{array}{c}\text { Relative } \\
\text { ethylene-forming }\end{array}$ \\
\hline L-Arginine & 100 & Imidazole & 62 \\
\hline D-Arginine & 3 & Imidazole-4-acetic acid & 37 \\
\hline L-Canavanine sulphate & 7 & $N$-Acetylimidazole & 57 \\
\hline L-Citrulline & 0 & L-Histidine & 100 \\
\hline L-Ornithine. $\mathrm{HCl}$ & 0 & D-Histidine & 89 \\
\hline L-Arginyl-L-arginine & 0 & 1-Methyl-L-histidine & 59 \\
\hline L-Arginyl-L-glutamic acid & 0 & Histamine & 45 \\
\hline Poly-L-arginine & 0 & $\mathrm{~N}$-Acetylhistamine & 50 \\
\hline $\mathrm{N}^{\mathrm{9}}$-Nitro-L-arginine & 0 & L-Carnosine & 11 \\
\hline$N^{\mathrm{g}}$-Tosyl-I-arginine & 0 & L-Histidyl-L-glycine & 33 \\
\hline $\mathrm{N}$-Carbobenzoxy-L-arginine & 0 & None & 50 \\
\hline None & $\mathbf{0}$ & & \\
\hline
\end{tabular}


Table 4. Effects of various reagents on the formation of ethylene

All concentrations were $1 \mathrm{mM}$, except for superoxide dismutase [150 units (ml reaction mixture $\left.)^{-1}\right]$, hydroquinone $(10 \mathrm{mM})$, catalase $\left.[0.05 \mathrm{mg} \text { (ml reaction mixture })^{-1}\right]$ and $\mathrm{H}_{2} \mathrm{O}_{2}(0.03 \%)$. The specific activity of the ethylene-forming enzyme used was 660 units ( $\mathrm{mg}$ protein)

\begin{tabular}{lc}
\hline \hline \multicolumn{1}{c}{ Reagent } & $\begin{array}{c}\text { Relative } \\
\text { ethylene-forming } \\
\text { activity (\%) }\end{array}$ \\
\hline Control & 100 \\
Respiratory inhibitor $\mathrm{NaN}_{3}$ & 90 \\
Free radical reagents & 120 \\
Superoxide dismutase & 90 \\
Mannitol & 100 \\
Sodium benzoate & 1 \\
n-Propyl gallate & 90 \\
Uric acid & 60 \\
Hydroquinone & 20 \\
Transition metals and SH-reagents & 50 \\
CoCl & \\
CuSO & \\
MnCl $_{2}$ & 6 \\
DTNB & 0.7 \\
Chelating reagents & 1 \\
EDTA(Na) & 0.8 \\
Tiron* & \\
Others & 200 \\
Catalase & $0 \cdot 7$ \\
$\mathrm{H}_{2} \mathrm{O}_{2}$ & 130 \\
Ascorbate $^{*}$ & \\
\hline \hline
\end{tabular}

*4,5-dihydroxy-1,3-benzene disulphonic acid.

ence of D-arginine and L-canavanine sulphate were only $3 \%$ and $7 \%$ of that in the presence of $L$-arginine. From Table 3 it can be seen that (1) the activity with Dhistidine was about $90 \%$ of that with L-histidine; (2) the activity without L-histidine was about $50 \%$ of that in the presence of L-histidine; and (3) imidazole was somewhat stimulatory. These results strongly suggest that the role of L-histidine is not that of a ligand, as suggested in a previous report (see Fig. 4 of Nagahama et al., 1991), but that of a scavenger of active species of oxygen (Levine, 1983).

\section{Inhibitors and activators of the ethylene-forming enzyme}

The effects of a number of potential inhibitors and other reagents on the ethylene-forming activity of Ps. syringae were examined (Table 4). Strong inhibition by the chelating reagents EDTA and Tiron was observed, suggesting that some kind of complex with $\mathrm{Fe}(\mathrm{II})$ is involved in the enzymic reaction, as shown in Fig. 4 of our previous report (Nagahama et al., 1991). Divalent transition metals, such as $\mathrm{Co}(\mathrm{II}), \mathrm{Cu}(\mathrm{II})$ and $\mathrm{Mn}$ (II) may compete with $\mathrm{Fe}$ (II) in the formation of such a complex and interfere with the ethylene-forming activity of the enzyme. Some SH-groups in the enzyme may be important for activity given the inhibitory effect of DTNB. Superoxide and hydrogen peroxide are not involved in the reaction since superoxide dismutase and catalase were not inhibitory. The activation of the reaction by catalase implies the formation of hydrogen peroxide during the reaction. The involvement of hydroxyl radicals is also unlikely since the effects of mannitol and sodium benzoate were small. These results imply co-ordination with $\mathrm{Fe}^{2+}$ which may be loosely bound to the enzyme through its SH-groups. Other scavengers of free radicals, namely propyl gallate and hydroquinone, inhibited the reaction to a considerable extent. This effect should not, however, be attributed directly to the radical-scavenging properties of these reagents. They may also form complexes with $\mathrm{Fe}(\mathrm{II})$ and inhibit the reaction in a similar manner to EDTA. These results show that the purified ethylene-forming enzyme of Ps. syringae has remarkably similar properties to the enzyme from $P$. digitatum (Fukuda et al., 1989a). We are now studying the mechanism of ethylene formation by the ethylene-forming enzymes from $P s$. syringae and $P$. digitatum.

\section{References}

Fukuda, H., FujII, T. \& Ogawa, T. (1984). Microbial production of $\mathrm{C}_{2}$-hydrocarbons, ethane, ethylene and acetylene. Agricultural and Biological Chemistry 48, 1363-1365.

Funuda, H., FujI, T. \& OGaWa, T. (1986). Preparation of a cell-free ethylene-forming system from Penicillium digitatum. Agricultural and Biological Chemistry 50, 977-981.

Fukuda, H., Kitajima, H., Fuji, T., Tazaki, M. \& Ogawa, T. $(1989 a)$. Purification and some properties of a novel ethyleneforming enzyme produced by Penicillium digitatum. FEMS Microbiology Letters 59, 1-6.

Fuxuda, H., Takahashi, M., Funil, T., Tazaki, M. \& Ogawa, T. $(1989 b)$. An NADH : Fe(III)EDTA oxidoreductase from Cryptococcus albidus: an enzyme involved in ethylene production in vivo? FEMS Microbiology Letters 60, 107-112.

Goro, M. \& HYODO, H. (1987). Ethylene production by cell-free extract of the Kudzu strain of Pseudomonas syringae pv. phaseolicola. Plant and Cell Physiology 28, 405-414.

Goto, M., Ishida, Y., Takikawa, Y. \& Hyodo, H. (1985). Ethylene production by the Kudzu strains of Pseudomonas syringae pv. phaseolicola causing halo blight in Pueraria lobata (Willd) Ohwi. Plant and Cell Physiology 26, 141-150.

Hirel, Ph.-H., Schmitter, J. M., Dessen, P., Fayat, G. \& Blanquest, S. (1989). Extent of N-terminal methionine excision from Escherichia coli protein is governed by the side-chain length of the penultimate amino acid. Proceedings of the National Academy of Sciences of the United States of America 86, 8247-8251.

INCE, J. E. \& KNOWLES, C. J. (1986). Ethylene formation by cell-free extract of Escherichia coli. Archives of Microbiology 146, 151-158.

KenDE, H. (1989). Enzymes of ethylene biosynthesis. Plant Physiology 91, $1-4$.

LAEMmLI, U. K. (1970). Cleavage of structural proteins during the assembly of the head of bacteriophage T4. Nature, London 227, 680686. 
LEVINE, R. L. (1983). Oxidative modification of glutamine synthetase. Journal of Biological Chemistry 258, 11828-11833.

MANsouri, S. \& BUNCH, A. W. (1989). Bacterial ethylene synthesis from 2-oxo-4-thiobutyric acid and from methionine. Journal of General Microbiology 135, 2819-2827.

Nagahama, K., Ogawa, T., Fujil, T., Tazaki, M., Goto, M. \& FUKUDA, H. (1991). L-Arginine is essential for the formation in vitro of ethylene by an extract of Pseudomonas syringae. Journal of General Microbiology 137, 1641-1646.

Ogawa, T., Takahashi, M., Fujil, T., Tazaki, M. \& Fukuda, H.
(1990). The role of NADH :EDTA(III) oxidoreductase in ethylene formation from 2-keto-4-methylthiobutyrate. Journal of Fermentation and Bioengineering 69, 287-291.

SHIPSTON, N. \& BUNCH, A. W. (1989). The physiology of L-methionine catabolism to the secondary metabolite ethylene by Escherichia coli. Journal of General Microbiology 135, 1489-1497.

WALLER, J. P. (1963). The $\mathrm{NH}_{2}$-terminal residues of the proteins from cell-free extracts of Escherichia coli. Journal of Molecular Biology 7, 483-496. 